\title{
Franchise on Treaties Law in Indonesia as Continuous Business Model
}

\author{
Sri Hudiarini \\ Lecturer in State Polytechnique of Malang, Indpnesia \\ Soekarno Hatta Street No. 9, Malang, 65141
}

\begin{abstract}
Today the growth of the business world is growing so rapidly, it is also supported to expand the business which is more varied, including through franchise (Franchise). Which of these principles for some entrepreneurs is considered more effective, effective and profitable in the development of a business. In Indonesia, the regulation of franchises is based on agreements made by the parties on the basis of the applicable law, in this case the Government Regulation and the Minister of Trade Regulation. Franchise is a form of business that gets a lot of attention from business people, because it can be one way to increase economic activity and give opportunity to weak economic class to try, this means, Franchise can provide job opportunity, equality and also create field work for the community. In addition, the profits of this business are low cost and the materials already provided are also not too take place so vast, franchise recipients no longer need to bother developing their business by building a good and famous image. It is enough to ride on the famous fame of the franchisor, so franchisees who are generally small entrepreneurs will enjoy the success and luck of large-scale companies without having to carry out their own research and development, marketing and promotion that usually requires enormous expenses that the small businessman is unlikely to bear.
\end{abstract}

Keywords: Business World, Franchise, Regulation, Entrepreneurship

DOI: $10.7176 / \mathrm{JLPG} / 91-05$

Publication date: November $30^{\text {th }} 2019$

\section{Introduction}

Basically, franchise is an agreement on delivery method of goods and services to customers. Franchisor grants licenses to franchisee to distribute goods and services in certain areas under franchisors' name and identity in and the business activities should be conducted in accordance to procedures set by the franchisor providing assistance to to franchisee. As a return, franchisee pays money in the form of initial fee and royalty (Suharnoko, 2004).

Franchise is also a business settlement in which a certain company (franchisor) grants a right to independent party (franchisee) to sell product or services of the franchisor based on the procedures set by franchisor. Franchisee uses brand, goodwill, product, services, distribution procedures, skills, operational system and supporting facilities of franchisor. For the return, franchisee pays royalty (cost for management services) to franchisor as stated in franchise agreement.

In order to improve stewardship of franchise business in Indonesia, there should be an active effort to develop national businessmen especially those of small and medium business into competitive franchisors which are able to compete in domestic and international market. Thus, government should take an active participation to manage franchise business (Satjipto Rahardjo, 1978, page 13) by enacting the Government Legislation no 42 of 2007 and Regulation of Ministry of Trade no 53 of 2012 on The Organization of Franchise.

Franchise is favourite business in Indonesia. It is reflected from the increasing number of franchisee. General Chief of Franchise and License of Indonesia, Levita Ginting Supit, states that market value of franchise business in 2017 is 200 trillion rupiahs for domestic or international franchise business. It shows that franchise is potential business in improving economy and absorbing employees in Indonesia.

Franchise businessmen in Indonesia expect that revision of regulation on franchise by Indonesian government is able to develop industry. Levita Ginting Supit, general chief of Franchise and License business association, said that regulation is problem of franchise business in Indonesia. She also said that Franchise association and government represented by Ministry of Trade is revising government regulation to support and protect domestic franchise business from the coming of international business.

However, prevailing regulation should support franchise businessmen to develop their business. Their business development will give positive influence for Indonesia economy because of the tax paid, improvement of local product use, and increasing number of demand of local product. Levita states that revision of regulation has been conducted since last year and it is now close to its completion. Franchise business association is also involved to give input for the revision in order that government and businessmen are able to develop the franchise business.

In addition, Levita also stated that revised version of regulation will be in effect in the middle of 2018. The association expects that the revision will be able to create conducive business atmosphere both for domestic and 
international business. Further, she said that domestic franchise business should be host firms in our own land. International franchise businesses should also be run by Indonesian in the form of business partnership. Therefore, it is expected that regulations will be able to support domestic and international businessmen to develop franchise business.

Research problem explored in this article is that how prevailing laws are able to give protection amidst the development of franchise business in Indonesia? What if it is reviewed by using Islamic law; and how is the development of international franchise business?

\section{History of Franchise Business}

Franchise was started in America by company producing Singer sewing machine in 1850's. At that time, distribution of Singer covered almost all area of America. Besides selling sewing machines, all distributors also provided after-sales service and spare parts. In addition, the distributors provided maintenance and repair service to customers (Deden Setiawan, (2007) page: 13).

However, according to another source, company following Singer is not Coca Cola but General Motors, an automotive company, founded in 1898 . The pattern was then accommodated by oil industry founding gas station network and also soft drink industry. They were producers without having distribution channel for their products. Therefore, they made use franchise system at the end of $18^{\text {th }}$ century and at the beginning of $19^{\text {th }}$ century. After World War II, retail industry has transformed their business from product-oriented into service-oriented industry. It was because middle-class people were highly mobile and settled in the suburb area; then there were many regular or drive-in restaurants specializing in fast-food menus.

At first, franchise was not familiar in Indonesian Law because it is not our culture or business tradition prevailing in Indonesia. However, due to globalization, franchise has been taken into culture and law order o Indonesia (Tengku Keizirina Devi Azwar, (2005), page 1-2).

\subsection{Definition of Franchise}

Franchise implies that a franchise businessman has freedom to run his own business in certain area (Richard Burton Simatupang, 2003, page 56). Franchise is a method of conducting business; it is also a method to deliver product or services to the people.

Rooseno Harjowidagdo states that franchise is granting rights by franchisor to Franchisee to use unique or special characteristic of their business in trading goods or services in the form of products or other forms such as company identity (logo, brand and company design, business plan usage and other supporting efforts, operational hours, working clothes and employee's performances); thus special business characteristics of franchisee are similar to those of franchisor" (Rooseno Harjowidagdo, 1993, page 1).

On the other side, according to Douglas J. Queen, franchise is method to expand marketing and business network by using similar marketing and operational standards. Franchise licensee buying certain business might take benefit and customer awareness for the brand, system and other services provided by franchisor" (Douglas J Queen, 1993, page 40).

Regulation of Ministry of Trade of Indonesia no 53 of 2012 on Franchise Organization states that franchise is special right possessed by person or business enterprises for business system having special characteristics in order to sell products and/or services that might be used by other parties based on certain agreement. In addition, franchise might be defined as system of marketing goods and services in which a franchisor grants special right to individual or small to medium scale business (franchisee) to conduct certain business system based on predetermined procedures, duration of time, and certain area coverage (Richard Burton Simatupang, 2003; page 56).

\subsection{Types of Franchise Agreement}

According to Suhrawardi K Lubis, franchise is granting right by franchisors to franchisee to use unique or special characteristics or business identification mark of franchisor in the form of product and other business characteristics including company identity (logogram, brand, company design, marketing plan usage and extensive supports, operational time, clothes and performance of employees) to deliver products/services. Therefore, uniqueness of business or special mark of identification of products or services of franchisee are similar to those of franchisor".

Brayce Webster states that there are three types of franchise. They are:

a) Product franchising. It is type of franchise in which franchisor grants license to franchisee to sell their product and franchisee functions as product distributor of franchisor. Often, franchisees are granted exclusive rights to market certain products in certain areas. The example of this type of franchise is car dealer and gas stations.

b) Manufacturing franchise franchisor. In this type of franchise, franchisee sells certain goods to sell products by using production standards and brand which are similar to those of franchisor. This type of 
franchise is commonly used in producing and distributing soft drink such as Coca Cola and Pepsi.

Business format franchising. It is franchise type in which franchisee conducts certain business activities by using franchisor name. For the return of using franchisor name, franchisees are required to follow certain operation method and supervised by franchisor to determine materials, location and design of business, marketing hour, requirements of employees and others. In addition, franchisor grants all business concepts including marketing strategies, guidelines and business operating standards and other supports in operating franchise. Therefore, franchisee has inseparable identity from franchisor (David, 1995).

In franchise, legal foundation of franchise is contract between the two parties. Franchise contract states that franchisee is independent contractor and not agent or employees of franchisor. However, franchisor is able to rescript the contract if franchisee violates the requirements stated in contract. In addition, license give is an agreement granting right and special authorities to franchisee. According to Mariam Darus Badrulzaman (2005 page 27), elements contained in franchise are:

1. It is an agreement.

2. It includes products/services delivery by using brand of franchisor.

3. Franchisor provides franchisee supports on marketing, managements and other technical supports.

4. Franchisee pays certain amount of fee or royalty for the use of brand of franchisor.

The agreement is valid for those involved. The agreement could not be cancelled - except it is approved by both parties for reason that is referring to prevailing regulations. The agreements should be based on good will (Mariam Darus Badrulzaman, 2005 page 27). Thus, franchisor agreement made by franchisor and franchisee is prevailing regulation for both. Indonesian Civil Code doesn't put franchisor agreement as statutory agreement like sales and purchase agreement, rent agreement and others. There must be mutual approval for an agreement and it will be basis for upcoming requirements. After all requirements are approved, then the agreement is valid as regulation for related parties as stated in article 1338 verse 1 of Indonesian Civil Code.

In addition to the two principles, there must be also good will for both making agreement. Principle on good will is stated in article 1338 verse 3 of Indonesian Civil Code stating "an agreement should be made with good will basis". Parties involved in an agreement should obey the provision of article 1320 of Indonesian Civil Code on the requirements of eligibility of an agreement namely approval of relevant parties, law competence of relevant parties, legal cause and others.

\subsection{Contract Law Aspect In Franchise}

Contract is an English term. In Dutch, it is called Overeenscom-strecht. In its classical view contract is also called "agreement". However "contract" is the most modern, most extensive and most-commonly used term in business context. Contract is a promissory agreement between two parties that may modify or dismiss legal relation (Munir Fuady, 2002, page 91). Definition of contract or agreement is stated in article 1313 of Indonesian Civil Code stating "An Agreement is legal act in which one party binds himself to one or more parties".

Further, it is also stated that all actions have legal impacts (rechtgevolg) and it is only legal action causing legal impact. In article 119 of Indonesian Civil Code, there are two types of contract namely nominaat contract (statutory/benoemde) and inominaat contract (unstatutory) which are under book III of Indonesian Civil Code. Innominaat contract comes up and develops in society such as contract of productions haring, joint venture, contract of work, construction contract, leasing, franchise, contract management, and technical assistance contract. Nominaat contract is that known and stated in article 1319 of Indonesian Civil Code stating "all agreements, either with special name or those unknown under special name, should obey general regulation stated in this chapter and previous one" (Syahrin Naihasy, 2005, page 67).

Nominaat contracts are those such as sales and purchase contract, exchanges contract, rent contract, civil partnership, bequest, bailment contract, lending contract, mandate, debt warranty contract, settlement contract, and others. To complete contract law, then a nominaat should fulfil five aspects (Syahrin Naihasy, 2005; page 68). They are

1. Principles of law, either written or unwritten one;

2. Law subjects; to support the right and obligation;

3. Law objects; which is closely related to performance basics;

4. An approval as the manifestation of willingness of those related parties on the substance and object of contract;

5. Legal consequences which is closely related to right and obligation of relevant parties.

\subsection{Principle of Contract Law}

According to Indonesian Civil Code, principle of contract law are guidelines that must be obeyed by those binding themselves in legal contract relations. According to HS Salim 2003 page 34-35, there are 5 principles of main legal basis of contract. They are

a. Freedom of contract. Arrangement system of contract is open system meaning that each person is 
free to make agreement which is either stated or not stated in prevailing legislation.

b. Conceptualism principle. It is reflected from article 1320 verse (1) of Indonesian Civil Coe. This article states that one of the requirement for an agreement to be valid is approval of both parties. Conceptualism principle requires that agreement may not be formulated formally as long as both parties approve it. The agreement might be reached due to alignment of willingness and statements of both.

c. Principle of Pacta Sunt Servanda or principle of law certainty. It is related to the impact of agreement. Principle of pacta sunt servanda requires that judges or third parties should respect the substance of contract. They may not interfere contract substance. The principle might be seen in article 1338 verse (1) of Indonesian Civil Code stating that "an agreement made is valid as regulation".

d. Principle of good will (Goede Trouw). It is reflected from article 1338 verse (3) of Indonesian Civil Code stating "An Agreement should be based on good will". The principle requires that relevant parties, namely creditor and debtor should conduct the contract substance based on trust or belief or good will. It is also closely related to Personality principle requiring that contract is made for the interest of certain party. It is shown in article 1315 and 1320 of Indonesian Civil Code stating "in general, a person could not bind himself or make an agreement for others except himself'.

In Indonesia, legal protection for franchise is stated in Book III of Indonesian Civil Law as general regulation and Government Legislation no 42 of 23 July 2007 on franchise. Article 1 verse (1) states the definition of franchise as "special right possessed by person or business entity for business system having special characteristics to deliver products/services and they may be used by other parties based on franchise agreement". There are two parties involved namely franchisor and franchisee who binds themselves to each other by franchisor agreement.

Article 1 verse (2) states that franchisor or franchisor right giver is person or business entity granting right to use his franchisor to franchisee. In addition, in article 1 verse (3), it is stated that franchisees are persons or business entities using franchise given by franchisor.

Furthermore, article 3 states that there are six requirements that must be fulfilled for franchise. They are:

a. Having special business characteristics giving competitive value for the franchise that cannot be imitated and making customers feel attracted;

b. The business is proven to be profitable. The franchisors have been knowledgeable in the business field for more than 5 years and they are able to tackle problems for their business to survive and become more profitable.

c. The franchise has excellent standard for goods and services offered. The franchise needs written standards in order that the franchisee is able to run the business based on fixed working plans known as standard operating procedures.

d. It is easy to teach and apply that inexperienced franchisee may run the franchise with the assistance of franchisor.

e. There should be continuous support from franchisor to franchisee.

f. There should be registered intellectual rights.

Government legislation no 42 of 2007 article 4 verse (1) states that franchise is conducted based on written agreement between franchisor and franchisee by taking Indonesian law into account. In addition, on article 4 verse (2), it is stated also that for agreement written in foreign language as stated in verse (1), it must be translated into Indonesia. Thus, if the franchisor is foreigner and franchisee is Indonesian, then the agreements should refer to government legislation no 42 of 2007 on Franchise.

Then, in article 6 verse (1) it is stated that franchise agreement may cover clauses of granting right for franchise to appoint other franchisee and in verse (2), it is also stated that franchisee having right to appoint other franchisee should have and run the franchise at least for 1 (one) year.

Article 7 states that franchisor must give franchise offering prospectus to candidate of franchisee. In addition, franchisor is also required to provide continuous assistance in the form of training, guidance of management, marketing, research and development to franchisee (article 8). Franchisor should also prioritize the use of domestic goods and services as long as they comply with goods and services standards set by franchisor (article 9 verse 1 ).

Provision and procedures to issue Registration Letter o franchisor is stated in Legislation of Ministry of Trade of Indonesia no 12/M-DAG/PER/3/2006 on 29 March 2006. The legislation states that franchisor is put in the written in Indonesia and contains: a. Name and addresses of related parties; b. Name and type of intellectual right or special business characteristics such as management system, marketing procedures or product layout or distribution of franchise object; c. Right and obligation of relevant parties, assistance as well as facilities provided by franchisor in Indonesia to franchisee; d. Area coverage (zone) of franchise; e. Agreement duration of time; f. Termination, continuation and discontinuation of contract; g. Dispute settlement; h. Payment 
procedures; i. Assistance, guidance and training for franchisee; j. Ownership and inheritor. In case of termination of agreement, franchise might demand for compensation and fulfilment of requirements.

\subsection{Franchise in Moslem Law}

Franchise is development of cooperation (syirkah) in which franchisor and franchisee cooperates for certain duration of time (in accordance to agreement) aiming at reaching mutual profit. It will creates job opportunities for people and improves prosperity because franchise offers comfortable facilities, cleanliness and competitive price as well as high quality product.

Etymologically, asy-syirkah is mixing between one thing with another making them hard to be differentiated. Asy-syirkah is also one of the trade cooperation based on certain requirements which is called trading federation in positive law (Nasrun Haroen, 1996, page 165). Syirkah or musyarakah is covenant of cooperation between two parties or ore for certain business in which each of them provides fund and agrees that profit and potential risks will be taken mutually as stated in agreement (Djuwaini, Dimyauddin, 2008).

In Moslem law, there are several definition os syirkah given by moslem law scholars (fukaha). One of them is Ulama Hanafiyah defining that syirkah as an agreement between two persons or more to obtain profit. In addition, Ulama Malikiyah states that syirkah is participation of two or more people in a certain transaction. Another law scholar, Ali Al-Khafit gives broader definition that it is a contract between two or more people to work together providing capital or their participation in others' capital and profit or their participation in profit but not capital [Umar Foundation Maoghul 2007 page 475).

Based on the above-mentioned definition, substance of syirkah covenant is contract of cooperation between two persons or more in business or trade. The profit and loss will be taken mutually.

Syirkah might be divided into two namely syirkah amlak (possession) and syirkah uqud (covenant).

1. Syirkah al-Amlak occurs when two or more persons has an object. The syirkah is divided into: Syirkah of Jabriyah which occurs without the willingness of related persons. For instance, inherintance properties belong to those receiving them. Syirkah of Ikhtiyariyah which occurs due to the willingness of related parties. For instance is two persons who agree to buy a good and it belongs to them (Sayuthi Thalib, 1986, page 79-83).

2. Syirkah al-Uqud is partnership between two persons or more based on a covenant (agreement) in which they agree to provide capital and to share profit and loss (Muhammad Syafi'i Antonio, 2011, page 91-92).

In Moslem law, there are two substances of franchisee contract. They are covenant substance which is close to syirkah covenant to share profit and which is close to ijarah covenant in which there is ownership shift of intellectual right from franchisor to franchisee on certain duration of time. Disclosure, honesty and carefullness are required for relevant parties. Franchise agreement is allowed in Moslem context provided that it complies with requirements of agreement, requirements of muamalah. Franchisee mostly brings positive impacts to small scale industry. Therefore, government should be more consistent in granting license of minimarket by for instance determining the distance of minimarket with traditional market in order to protect small scale business.

Referring to operational aspects of franchise, we know that Moslem law allows franchisor agreement as long as it complies the requirements and basic principles of mu'amalah. It means that the agreement is allowed and valid if it complies with prevailing requirements and legislation. Competition arouse is positive because franchise provides comfortable facilities and reasonable price.

According to Moslem law, there are several factors that should be reviewed to highlight its position. They are :

1. Types of products or services. They must not contain substances which are forbidden for instance food product from pigs, animals with fang, dead animals, blood, or other harmful substances;

2. Franchise should be profitable business so that franchisee may get profit. Therefore, money paid to franchisor is profit buying for intellectual right. It is because Islam forbids us to buy something which is useless for franchisee.

3. Cooperation agreement should be clear and transparent to prevent future disputes and fraud.

4. Agreement should comply with Moslem rules because those against Moslem rules are bathil such as agreement of riba or gambling.

\subsection{Development of Franchise in International Business}

Franchise agreement is business transaction and is arranged in International Code of Law due to foreign element between franchisor and franchisee. If each country uses its own rules, then it should be stated clearly on which legislation that will be used for the agreement. There are several possibilities on legislation used for franchise (Bambang Tjatur Iswanto, 2007: 40) because each party has his own right and obligation stated in franchisee agreement conducted in related countries.

Further, Bambang Tjatur Iswanto stated that in franchise agreement, the legislation might be determined by related parties or based on general principles of international contract. British Franchise Association defines franchise as license agreement given by franchisor to franchisee which contain:

1. Giving right to franchisor to supervise franchisee during stated period of time. 
2. Requirements of franchisor to assist franchisee in conducting his business by using his franchise subject (it is related to training, merchandising et cetera).

3. Requirements of franchisee to pay for some money for products or services given by franchisor to franchisee.

4. It is not transaction between Holding company and its branch or between branch with similar holding company or between individuals with company.

According to Juajir Sumardi (1995; 46-47), franchise agreement is made by franchisor and franchisee in which franchisor grants right to franchisee to produce or sells his products and or services at predetermined areas and on certain duration of time under supervision of franchisor. Franchisee pays certain amount of money for the right.

The practice might be seen from franchisee business (Santoso Lolowang) such as fast food such as Kentucky Fried Chicken, Mc Donald, Pizza Hut, and fitness center. It encourages competition between franchisee. Furthermore, franchise is known not only for developing international investment but also marketing technique helping local small business. In Indonesia, the condition is influenced by deregulation by government in business context. In other countries, franchise develop even faster.

European communities have formulated franchising agreement regulation in 1988 which gives warranty for the countries to franchising monopoly. Santoso Lolowang also states that, franchise business develops fast in Asean countries. For instance, education institution franchise namely International Language Program (ILP) will be founded in ASEAN countries including China.

In Telematics or Information \& Communication Technology, franchisor business such as printer refill/cartridge business (Inke, X4print, Veneta etch), Computer Course franchise (Widyaloka, Binus), computer spare parts distribution franchise (Micronics Distribution), Internet Caffee (Multiplus, Java NetCafe, Net Ezy), Consultant office et cetera are example of franchise business which are developing. Another profitable franchises are those of education such as Science Budies, Primagama, Sinotif, Robota Robotics School, English Language Education such as EF/English First, ILP, Direct English.

\title{
4. Conclusion
}

Business develops at extensive pace in Indonesia and one of them is franchise. This business is effective and profitable. In Indonesia, business activities of franchise should be based on contract containing legal guidelines arranging approval or agreement between legal subjects. In Indonesia, it is stated in Indonesian Civil Code, Government Legislation and Legislation of Ministry of Trade.

Article 1 of Government regulation no 42 of 2007 states that franchise is special right possessed by person or business entity of business system with special characteristics to sell products and/or services which are profitable. Those involved are franchisor and franchisee binding themselves in franchise agreement.

According to Moslem Law, there are two substances of franchise contract. They are covenant substance which is close to syirkah covenant shown by bussiness partnership in which related parties agrees to share profit and covenant substance which is close to ijarah covenant shown by ownership shift of intellectual right from franchisor to franchisee for certain duration of time. Disclosure. Honesty and carefulness aspect are required from both parties. Franchise agreement is allowed in Moslem law as long as it complies with the principle of muammalah. In addition, there are several factors that must be taken into account in order that the agreement complies with Moslem law. The first is that the products must be legal. The franchise should be profitable and the agreement must be clear and transparent to prevent future dispute.

In international business, franchise is regulated in International Civil Law due to foreign elements between franchisor and franchisee. It includes selling brand or famous products to foreign countries. Therefore, this is contract referring to international law.

Government supervision is required for approving agreement between the two parties to prevent loss in franchise. There should be socialization on law regulating franchise business. In addition to contract formulation, franchisor should take benefit for himself or franchisee into account. It is crucial because franchise business in Indonesia (making agreement with foreign franchisor) will obtain added value in their business.

\author{
References \\ Azwar, Tengku Keizerina Devi (2005), Perlindungan Hukum Dalam Franchise, Jakarta \\ Badrulzaman, Mariam Darus (2005) Aneka Hukum Bisnis, Bandung: Alumni \\ Setiawan, Deden (2007) Franchise Guide Series-Ritel, Jakarta: Harian Dian Rakyat \\ Fuady, Munir, (2002), Pengantar Hukum Bisnis, Bandung: Citra Aditya Bakti \\ Naihasy, Syahrin, (2005), Hukum Bisnis (Business Law), Yogyakarta: Mida Pustaka \\ Douglas J. Queen, (1993), Pedoman Membeli dan Menjalankan Franchise, Jakarta: PT. Elex Media \\ Komputindo, Gramedia \\ Rahardjo, Satjipto, (1978), Permasalahan Hukum Di Indonesia, Bandung: Alumni
}


Harjowidagdo, Rooseno, (1993), Perspektif Pengaturan Perjanjian Franchise, Jakarta, BPHN Departemen KeHKIman Republik Indonesia

HS, Salim, (2003), Hukum Kontrak, Jakarta: Sinar Grafika

Simatupang, Richard Burton, (2003), Aspek Hukum Dalam Bisnis, Jakarta : Rineka Cipta

Djuwaini, Dimyauddin, (2008), Pengantar Fiqh Muamalah, (Yogyakarta ; Pustaka Pelajar)

Antonio, Muhammad Syafi' I, (2001), Bank Syari'ah dari Teori ke Praktek, Jakarta; Tazkia Cendekia

Subekti, R dan Tjitrosudibio, R, (1978), Kitab Undang-Undang Hukum Perdata, Burgerlijk Wetboek, Pradnya Paramita, Jakarta.

Sumardi, Juajir,(1995), Aspek Aspek Hukum Franchise dan Perusahaan Transnasional, Bandung, Citra Aditya Bakti

Sayuthi Thalib, 1986, Hukum Kekeluargaan Indonesia, ( PT Jakarta ; UI Press.)

Nasrun Haroen,, 1996, Ushul Fiqh I, Jakarta ; Logos

\section{Articles}

Iswanto, Bambang Tjatur. (2007), Perlindungan Hukum Terhadap Franchise Dalam Perjanjian Franchise di Indonesia, Tesis S2, Program Pascasarjana Ilmu Hukum, Universitas Diponegoro, Semarang

Maoghul, Umar F. (2007), No Pain, No Gain: The State of The Industry in Lightof an American Islamic Private Equity Transaction, Chicago : Journal International Law, Vol. 7, Iss, $2: 26$ pgs.

Hess, David. (1995). "The Lowa Franchise Act : Toward Protecting Reasonable Expectations of Franchisees and Franchisors", Vol 80. Januari 1995

Idrus, Norman Syahdar, Aspek Hukum Perjanjian Waralaba (Franchise) dalam Perspektif Hukum Perdata Dan Hukum Islam, Jurnal Yuridis UPN Jakarta Vol 4 no.1 2017

Slamet, Sri Rejeki., Waralaba (Franchise) di Indonesia 127 Lex Jurnalica Vol 8 No. 2, April 2011

Rival, Muchtar, Pengaturan Waralaba Di Indonesia; Perspektif Hukum Bisnis, STIE Achmad Dahlan Jakarta, Jurnal Liquidity, Vol 1. No. 22012

\section{Peraturan Perundangan}

Peraturan Pemerintah no 42 thn 2007 tentang Waralaba

Peraturan Menteri Perdagangan no 53 tahun 2012 tentang Penyelenggaraan Waralaba

\section{Website}

http://industri.bisnis.com/read/20180222/12/741801/bisnis-waralaba-pertumbuhan-usaha-masih-akan-ngebuttahun-ini

http://industri.bisnis.com/read/20180222/12/741805/bisnis-waralaba-indonesia-nantikan-revisi-regulasi

https://books.google.co.id/books?hl=en\&lr=\&id=HONUDwAAQBAJ\&oi=fnd\&pg=PA45\&dq=waralaba + dalam +hukum+islam\&ots $=$ dh4ckM41-

\&sig=q8ANssIMprC1IYf5w_ZnS60TL1Y\&redir_esc=y\#v=onepage\&q=waralaba $\% 20 \mathrm{dalam} \% 20 \mathrm{hukum} \% 2$ 0islam $\& \mathrm{f}=\mathrm{false}$ 